\title{
Physiological and phytosanitary potential of rocket seeds
}

\author{
Potencial fisiológico e fitossanitário de sementes de rúcula
}

\author{
Jucilayne Fernandes Vieira ${ }^{\mathrm{I}^{*}}$ Sandro de Oliveira ${ }^{\mathrm{I}}$ Zarela Casas Navarro Zanatta $^{\mathrm{I}}$ \\ Elisa Souza Lemes ${ }^{I}$ Francisco Amaral Villela ${ }^{I}$ Antonio Carlos Souza Albuquerque Barros ${ }^{I}$
}

\section{ABSTRACT}

The objective of this study was to evaluate the physiological and sanitary quality of seeds of rocket; the research was done at the Laboratory of Seed Analysis and greenhouse of the Department of Plant Science, Federal University of Pelotas (UFPel). Four lots of the cultivar "Antonella" were tested for following features: initial and final moisture content, germination rate, first count of germination, accelerated aging with saline solution, dry matter contents, seedling shoot and root length, emergence speed index, emergence of seedlings in substrate, electrical conductivity and sanitary condition. A completely randomized design with four replications was used for all tests done and means were compared by Tukey test $(P \leq 0.05)$. For all tests performed it was concluded that despite changes in the ranking of the best lots, there was agreement regarding the indication of the inferiority of the lot 3 in all tests and it was also observed that the incidence of fungi associated with seeds of rocket interfere with the physiological quality of the lots.

Key words: Eruca sativa L., vigour tests, vegetable seeds. RESUMO

O objetivo nesta pesquisa foi avaliar a qualidade fisiológica e sanitária de sementes de rúcula. O trabalho foi conduzido no laboratório e em casa de vegetação do Departamento de Fitotecniada Universidade Federal de Pelotas (UFPel). No ensaio, foram utilizados quatro lotes de sementes de rúcula da cultivar 'Antonella', sendo efetuados os seguintes testes: grau de umidade inicial e após o envelhecimento acelerado, germinação, primeira contagem de germinação, envelhecimento acelerado com solução salina, massa seca da parte aérea e de raiz de plântulas, comprimento da parte aérea e de raízes de plântulas, indice de velocidade de emergência, emergência de plântulas, condutividade elétrica e teste de sanidade, em delineamento experimental inteiramente casualizado, com quatro repetições, sendo que as médias foram comparadas pelo teste de Tukey $(P \leq 0,05)$. Apesar das alterações na classificação dos melhores lotes, nos testes analisados, verificou-se concordância quanto à indicação da inferioridade do lote 3 em todas as avaliações. Verificou-se que a incidência dos fungos associados às sementes de rúcula interfere na qualidade fisiológica dos lotes.

Palavras-chave: Eruca sativa L., testes de vigor, sementes de hortaliças.

\section{INTRODUTION}

The rocket plant (Eruca sativa L.) is an herbaceous annual vegetable of low-height, usually 15 to $20 \mathrm{~cm}$ height, which belongs to the family of Brassicaceae and is native to the Mediterranean Region and West Asia (FILGUEIRA, 2008). It is a vegetable with a growing increase in consumption in Brazil (CAMARGO FILHO \& MAZZEI, 2001) and the high cost of seeds and hand labor involved in its cultivation requires studies that relate the quality of seeds to seedling emergence, in order to determine the cause of crop losses (GOULART \& TILLMANN, 2007).

The physiological quality of seeds used by farmers is a major factor to be considered for the deployment of the crop and there is consensus among researchers, technologists and producers of the importance of vigor and the need to evaluate it (KOLCHINSKI et al., 2006) because high vigor seed lots show rapid and uniform seedlings emergence, which are essential to the formation of well-developed plants, thus contributing to increase the final yield of the crop and quality of the commercial product (MARCOS

\footnotetext{
IPrograma de Pós-graduação em Ciências e Tecnologia de Sementes, Departamento de Fitotecnia, Faculdade de Agronomia Eliseu Maciel, Universidade Federal de Pelotas (UFPEL), CP 354, 96010-900, Pelotas, RS, Brasil. E-mail: laynevieira@yahoo.com.br. *Corresponding author. Received 05.24.13 Approved 07.20.14 Returned by the author 09.13.14 CR-2013-0728.R4
} 
FILHO \& NOVEMBRE, 2009; DALIL et al., 2010). In addition to the use of high quality seeds for the establishment of uniform and vigorous crops, there is a concern over the presence of pathogens associated with seeds because contaminated seeds are responsible for the introduction of disease in early stages of the culture of crops, reflected in reduced yields, increased costs of production, and allow the introduction and maintenance of high levels of inoculum in the field (MACHADO, 2000; ZORATO \& HENNING, 2001; LUZ, 2003).

The presence of pathogens in the seeds, regardless of their transmissibility can affect the vigor and field performance and fungi associated with seeds may be responsible for transmitting diseases to shoot and root systems and decrease the physiological quality of seeds and increase the risk of seedling death (LUCCA-FILHO, 1995). In this context, high vigor seed and free of pathogens are essentials (MACHADO, 2000) and the physiological potential should be determined by assessing germination and vigor of the seed lots because seed vigor has several characteristics associated with the performance of the seed lots, being able to identify results of their behavior during storage or in the field (MARCOS FILHO, 2005).

Several tests of vigor for vegetable seeds have been published, but the availability of information on the evaluation of vigor of rocket seed is still quite limited, but the following works can be cited: the efficiency of the accelerated aging test was explored by RAMOS et al. (2004) and GOULART \& TILLMANN (2007) have evaluated the employability of the controlled deterioration test and the electrical conductivity and STEINER et al. (2010) has studied seed germination under different temperatures. In order to contribute to increase information about vigor and seed health of vegetable, this study aimed to evaluate the efficiency of different tests to determine the physiological quality and health of different lots of rocket.

\section{MATERIAL AND METHODS}

The work research using seeds from four seed lots of rocket cultivar 'Antonella' (from Isla Seed Company) were subjected to following tests and assessments:

Determination of moisture content: the moisture content of the seed was assessed before and after the accelerated aging test and the test was conducted in an oven at $105 \pm 3^{\circ} \mathrm{C}$ for $24 \mathrm{~h}$, in accordance with the Rules for Seed Analysis - RAS (BRASIL, 2009), using two samples of $4 \mathrm{~g}$ seeds for each lot and the results were expressed as mean percentage weight loss per lot.

Germination test: was conducted at $20^{\circ} \mathrm{C}$ with 200 seeds per seed lot (four replicates of 50 seeds); the seeds were distributed on two sheets of paper, previously moistened with distilled water in an amount equivalent to 2.5 times the mass of paper and placed inside transparent plastic boxes $(11.5 \times 11.5 \times 3.5 \mathrm{~cm})$ with lid. Evaluations were conducted at four and seven days after sowing and the results expressed in percentage of normal seedlings (BRASIL, 2009).

First count of germination: was made in conjunction with the germination test, by computing the percentage of normal seedlings on the fourth day after sowing (BRASIL, 2009).

Accelerated aging with $\mathrm{NaCl}$ solution: a total of 200 seeds (four replicates of 50) per lot were distributed over an aluminum screen placed inside a plastic box (gerbox) containing $40 \mathrm{ml}$ of $\mathrm{NaCl}$ solution, maintained at $41^{\circ} \mathrm{C}$ for 48 hours. This solution was prepared by adding $40 \mathrm{~g}$ of $\mathrm{NaCl}$ in $100 \mathrm{ml}$ of water, establishing an environment with relative humidity of $76 \%$, according to the procedure proposed by JIANHUA \& MCDONALD (1997). After this period, the seeds were put to germinate following the methodology used in the germination test described above and the percentage of normal seedlings was assessed on the fourth day after sowing, as described by GOULART \& TILLMANN (2007).

Drymattercontents: thesametwentynormal seedlings used for root and shot length measurement were also used for dry matter content measurement. The samples were dried in a forced-air oven at $60^{\circ} \mathrm{C}$ for $72 \mathrm{~h}$, cooled in a desiccator, and weighed.

Seedling shoot and root length: was conducted at $20^{\circ} \mathrm{C}$ with 80 seeds per seed lot (four replicates of 20 seeds); normal seedlings were taken from each replication for measuring the root and shoot length and the mean values were recorded in $\mathrm{cm}$.

Emergence Speed index: the number of emerged seedlings was counted daily until it reached a constant level (a period of 21 days). For each replication, the emergence speed index was calculated by summing the daily ratios of the number of emerged plants to the number of days from sowing using the formula described by MAGUIRE (1962).

Seedling emergence in substrate: a total of 200 seeds (four replicates of 50) per lot were distributed in polystyrene trays with 200 cells filled with commercial substrate Plantmax ${ }^{\circledR}$. Evaluations were performed at 12 days after sowing, computing 
the normal seedlings and the results expressed as percentage of normal seedlings emerged.

Electrical conductivity: the seeds were soaked in $200 \mathrm{~mL}$ plastic cups containing $50 \mathrm{~mL}$ of deionized water and the readings were taken at 2,4 , 6,8 and 24 hours and the test was done with four replications of 50 seeds per seed lot and values were expressed in $\mu \mathrm{S} \mathrm{cm}^{-1} \mathrm{~g}^{-1}$.

Seed health testing: the methodology of the paper filter or blotter test was used, eight sub samples of 25 seeds per seed lot were placed in plastic boxes containing three filter papers moistened with $-0.5 \mathrm{MPa}$ of osmotic potential of polyethylene glycol PEG 6000 (VILLELA et al., 1991). The seeds were incubated at $25^{\circ} \mathrm{C}$ for seven days under a photoperiod regime of 12 hours light and 12 hours of darkness and after the incubation period the seeds were examined individually for fungal growth using a stereomicroscope, and the incidence of pathogenic fungi was expressed as percentage seeds infected.

The experimental design was completely randomized layout and in the statistical procedure, analysis of variance was performed separately for each test and the means of the lots were compared by Tukey test at $5 \%$ probability. The conductivity test was analyzed in a factorial of 4 lots $\mathrm{x} 5$ seed imbibition periods and to seed health test was not analyzed by statistical test.

\section{RESULTS AND DISCUSSION}

The initial moisture content of the seeds from the four seed lots of rocket ranged from 5.5$7.5 \%$ (Table 1), this is within the maximum range of two percentage points accepted for guarantee credibility, according to MARCOS FILHO (1999). When analyzing the initial quality of the lots, it appears that they had a high germination percentage ranging from 86 to $93 \%$, which is higher than the minimum of $80 \%$ established for seed trading. However, in many cases a high germination percentage does not necessarily mean that all of these lots have a high vigor, since the germination test is conducted under favorable conditions.

The germination test sorted the lots at different levels of vigor, pointing to the low grade in physiological quality of lot 3, differing from lots 1 and 2 , but being equal to lot 4 . The germination test for other kinds of vegetables, such as zucchini (Cucurbita pepo L.) and zucchini cv. Piramoita, also managed to rank seed lots (CARDOSO, 2003). These authors demonstrated that for these species the germination test is a good indicator of physiological quality. Regarding seeds of cucumber (Cucumis sativus L.), BHERING et al. (2000) concluded that although the germination test proves to be a good indicator of physiological seed quality, it does not guarantee a high field emergence of lots with higher germination percentages.

The first count test separated the lots regarding their physiological quality; the seeds from lot 1 and 2 showed higher values, whereas lots 3 and 4 showed the worst performance. Similar results were obtained by CARDOSO (2003) with squash seeds, in this work, the lots were only sorted in high and low physiological potential. In cucumber and lettuce, the first count of germination has been routinely used to obtain preliminary information on the physiological potential of seed lots (BHERING et al., 2000).

The accelerated aging test was more sensitive than germination to detect differences in seed vigor and this test also confirmed the poor quality of the third lot and good quality of lots 1 and 2 and lot 4 was found to be intermediate quality (Table 1). In this study, the seed lots 1 and 2 had the lowest levels of water after the accelerated test, whereas, the highest values occurred in seeds of lot 3

Table 1 - Initial moisture content of the lots (IMC), moisture content after accelerated aging (MCA), percentages for germination test (G), first count of germination (FCG), accelerated aging with NaCl-76\% (AA), root and shoot dry matter (DM), root length (RL), shoot length (SL), emergence speed index (ESI), emergence of seedlings in substrate (SES) of the different lots of rocket seeds.

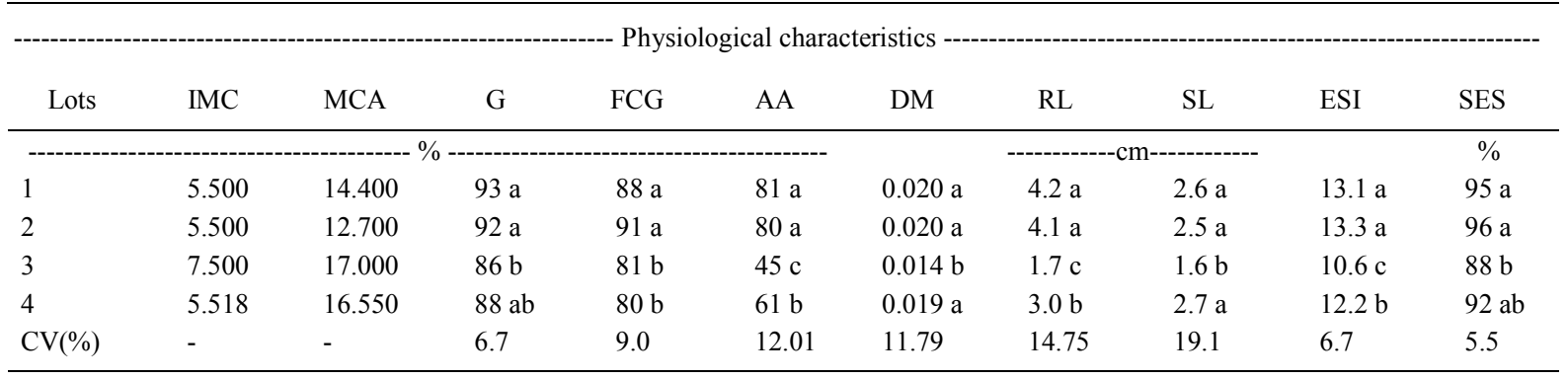

Means followed by the same letter in a column do not differ in level of 5\% probability by the Tukey test. 
and 4. This high water content may have influenced the seed germination in the aging test because seeds with low water content showed higher germination rates.

These results are similar to those observed by BHERING et al. (2000) and BARROS et al. (2002) that also found the efficiency of accelerated aging test using the period of exposure of 48 hours and $41^{\circ} \mathrm{C}$ for stratification of the seed lots of cucumber and zucchini respectively. Furthermore, another study conducted with seeds of rocket by GOULART \& TILLMANN (2007) has found that the accelerated aging test was efficient for evaluating quality of rocket seeds because this test was enable in demonstrating vigor differences between lots. The ability of the accelerated aging test to evaluate seed vigor was also observed in seeds of watermelon (BHERING et al., 2003), in this work they showed that the accelerated aging test with the use of salt solution promotes less drastic effects for achieving the lower water content and the degree of deterioration of the seeds is attenuated compared to the traditional method (when only water is used).

With the dry mass of seedlings assessed in days after emergence of seedlings substrate, two levels of physiological quality could be distinguished (Table 1). The seedlings from lots 1, 2 and 4 showed the highest content of dry mass, whereas, the seedlings from third lot had the lowest content of dry mass of shoot and root. In this test, the principle is that seeds whose normal seedlings have higher average contents are considered more vigorous. The flux of mass from storage tissue to the embryonic axis during seed germination is intense, resulting in seedlings with higher weights due to higher accumulation of material (NAKAGAWA, 1999).

The root of seedlings from the lots 1 and 2 were significantly higher than lots 3 and 4 , however, the dry mass of seedlings distinguished the lots in two levels as was observed for the shoots, in the other words, the seedlings from seed lots 1, 2 and 4 were statistically reliable higher than those of lot 3 (Table 1) and in both assessments, the third lot is considered to be of low physiological quality. According to NAKAGAWA (1999) differences in length of seedlings are most often quite visible; however, it is important to separate the more vigorous by numeric values. For this, determining the average length of normal seedlings or parts of them is performed in order that the samples which have the highest average values are more vigorous. BALBINOT \& LOPES (2006), working with carrot seeds studied the relationship between seed vigor and length of seedlings. The speed of emergence index has also showed sensitivity to rank lots of different physiological potential as a significant difference between the averages assessed (Table 1). It is important to emphasize, seed lots with greater physiological potential, mainly by higher rates of emergency speed, are important to obtain seedlings that remain a shorter time subject to adverse conditions, such as the presence of fungi that promote damping off and also by obtaining the earliest and most uniform seedlings (CASAROLI et al., 2006).

A significant interaction between time of seed imbibed and lots was observed (Table 2) and the electrical conductivity test also allowed differentiating levels of quality among seed lots of rocket showing in all imbibing periods that the test also identified the lot 3 as the less vigorous in relation to lots 1, 2 and 4. In other studies with carrot seeds (ANDRADE et al., 1995) and also with rocket seeds (ALVES \& SÁ, 2009), promising

Table 2 - Electrical conductivity test with soaking 50 seeds in $50 \mathrm{ml}$ of distilled water for periods of 2, 4, 6, 8 and 24 hours from four rocket seed lots.

\begin{tabular}{|c|c|c|c|c|c|}
\hline \multirow[t]{2}{*}{ Lots } & \multicolumn{5}{|c|}{ 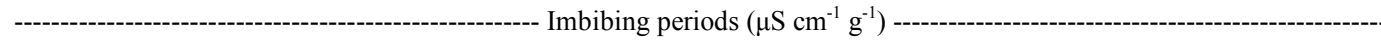 } \\
\hline & 2 & 4 & 6 & 8 & 24 \\
\hline 1 & $5.71 \mathrm{aA}$ & $8.20 \mathrm{aB}$ & $9.74 \mathrm{aC}$ & $10.76 \mathrm{aC}$ & $17.95 \mathrm{aD}$ \\
\hline 2 & $8.00 \mathrm{abA}$ & $9.06 \mathrm{aB}$ & $11.83 \mathrm{bC}$ & $12.86 \mathrm{bC}$ & $19.64 \mathrm{bD}$ \\
\hline 3 & $8.99 \mathrm{cA}$ & $11.85 \mathrm{bB}$ & $14.44 \mathrm{cB}$ & $16.00 \mathrm{cC}$ & $25.33 \mathrm{cD}$ \\
\hline 4 & $7.14 \mathrm{bA}$ & $9.01 \mathrm{aB}$ & $10.82 \mathrm{abB}$ & $11.9 \mathrm{abC}$ & $18.94 \mathrm{abD}$ \\
\hline $\mathrm{CV}$ & & & 10.8 & & \\
\hline
\end{tabular}

Means followed by the same letter in lower case in a column and capital letter on a line do not differ (Tukey test at $5 \%$ probability).

Ciência Rural, v.45, n.2, fev, 2015. 
results were found in assessments after four hours of imbibing. In this present study, all imbibing periods were effective in the classification of the lots and this test separated the lots by their quality levels. When the conductivity values are analyzed over the different periods, there is a lot like being the best quality with the system more intact cell membranes or with greater capacity to restore its integrity, during hydration, the less leaching of electrolytes, indicating a greater vigor, as suggested by studies in other crops (DIAS et al., 2006), confirming the results observed in other tests.

The results of the germination test obtained in laboratory are exactly in line with those obtained for the emergence of seedlings in the greenhouse using substrate (Table 1). Thus, differences in quality found in the lots 1 and 2 and 4, were confirmed in two tests, which exhibit the best physiological conditions, obtaining the highest percentage of emergence of the seedlings and lot 3 showed the lowest results. The vigor classification correspondence between germination test in the laboratory and seedling emergence of the lots may be due to the emergence of seedlings had been done in the greenhouse using as a support an inert substrate. This fact contributed to maintain the temperature and sufficient moisture for good seeds germination; in addition the substrate was absence of pathogen.

The higher incidence of fungi was observed for all lots belonging to the genera Aspergillus spp., Fusarium spp., Penicillium spp. and Rhizopus spp. However, the incidence varied between the different lots (Table 3) and the fungi found in this study can be classified into fungi that are transmitted to the seedlings and plants by seeds, such as Fusarium spp.,
Alternaria spp. and Cladosporium spp. and storage fungi, which are include other genera cited above.

The lot 3 had a higher incidence of fungi on seeds, this may explain the low viability and vigor found in that lot, and it showed that the high incidence of fungi limited the performance of this lot. In this paper was observed that the lots with a lower incidence of fungi, in general, showed higher values of seed germination and vigor. Thus, the sanitary quality of seeds can also influence the seeds vigor and the emergence of seedlings, and the sanity test should be performed to verify the quality of a seed lot produced.

\section{CONCLUSION}

All vigor tests used in this study were effective to separate the seed lots in vigor levels and the tests showed lot 3 as the worst physiological quality. The incidence of fungi associated with seeds of rocket interferes with the physiological quality of the lots.

\section{ACKNOWLEDGEMENTS}

We thank Coordenação de Aperfeiçoamento de Pessoal de Nível Superior (CAPES) for the scholarship for the first author and Conselho Nacional de Pesquisa e Desenvolvimento Tecnológico (CNPq) for the financial support for this work and we also wish to thank Dr. Pieter Kastelein from Wageningen University and Research Centre, Plant Sciences Group for making useful suggestions for this paper.

\section{REFERENCES}

ALVES, C.Z.; SÁ, M.E. Teste de condutividade elétrica na avaliação do vigor de sementes de rúcula. Revista Brasileira de Sementes, v.31, n.1, p.203-215, 2009. Available from: <http:// www.scielo.br/pdf/rbs/v31n1/a23v31n1.pdf $>$. Accessed: Jun. 15, 2011. Doi: 10.1590/S0101-31222009000100023.

Table 3 - Percentage of fungi obtained in the sanity test of the four rocket seed lots.

\begin{tabular}{lllll}
\hline Fungi & Lot 1 & Lot 2 & Lot 3 & Lot 4 \\
\hline Aspergillus spp. & 4.5 & 18.3 & 21 & 20 \\
Penicillium spp. & 0.3 & 12.33 & 8.66 & 37.66 \\
Fusarium spp. & 3.2 & 17.33 & 8.7 & 7.33 \\
Ryzopus spp. & 1.9 & 7 & 0.66 & 0 \\
Curvularia spp. & 0 & 0.3 & 2.6 & 0 \\
Cladosporium spp. & 0 & 0.6 & 1 & 0 \\
Nigrospora spp. & 0 & 0 & 0 & 0 \\
Epicoccum spp. & 0 & 0 & 0 & 0 \\
Stemphylium spp. & 0 & 0 & 1 & 0 \\
Alternaria spp. & 0.5 & 0.3 & 1.6 & 0 \\
Bipolaris spp. & 0 & 0 & 0 & 0.66 \\
Trichoderma spp. & 0 & 0 & 0 \\
Chaetomium spp. & 0 & 0 & 0 \\
\hline
\end{tabular}


ANDRADE, R.N. et al. Correlação entre testes de vigor em sementes de cenoura armazenadas por diferentes períodos. Pesquisa Agropecuária Gaúcha, v.1, n.2, p.153-162, 1995. Available from: http://www.fepagro.rs.gov.br/upload/1398957242_art_02.pdf. Accessed: Jun. 10, 2011.

BALBINOT, E.; LOPES, M.H. Effects of osmoconditioning and drying on carrot seed germination and vigor. Revista Brasileira de Sementes, v.28, n.1, p.1-8, 2006. Available from: <http://www. scielo.br/pdf/\%0D/rbs/v28n1/a01v28n1.pdf >. Accessed: May 13, 2011. doi: http://dx.doi.org/10.1590/S0101-31222006000100001.

BHERING, M.C. et al. Métodos para avaliação do vigor de sementes de pepino. Revista Brasileira de Sementes, v.22, n.2, p.171175, 2000. Available from: <http://www.abrates.org.br/revista/ artigos/2000/v22n2/artigo23.pdf>. Accessed: Mar. 18, 2011.

BHERING, M.C. Avaliação do vigor de sementes de melancia (C. lanatus) pelo teste de envelhecimento acelerado. Revista Brasileira de Sementes, v.25, n.2, p.1-6, 2003. Available from: $<$ http://www.scielo.br/scielo.php? script $=$ sci arttext\&pid $=\mathrm{S} 010$ 131222003000400001\&lng=pt\&nrm=iso>. Accessed: Mar. 18, 2011. doi: 10.1590/S0101-31222003000400001.

BARROS, D.I. et al. Evaluation of seed vigor of zucchini (Cucurbita pepo L.) by tetrazolium test. Horticultura Brasileira, v.20, n.2, p.1-5, 2002. (Suppl.2). 1 CD.

CAMARGO FILHO, W.P.; MAZZEI, A.R. Vegetable market planning, strategy and marketing. Economic Information, v.31, n.3, p.45-54, 2001.

BRASIL. Ministério da Agricultura, Pecuária e Abastecimento Regras para análise de sementes. Brasília: MAPA/ACS, Secretaria de Defesa Agropecuária, 2009. 395p.

CASAROLI, D. et al. Health and physiological quality of 'Menina Brasileira' squash seeds. Fitopatologia Brasileira, v.31, n.2, p.158-163, 2006. Available from: <http://www.scielo.br/scielo php?pid $=$ S 1807-86212009000200022\&script $=$ sci arttext $>$. Accessed: Jul. 07, 2014

CARDOSO, A.I.I. Production and quality of squash seeds "Piramoita" in response to pollen amount. Bragantia, v.62, n.1 p.47-52, 2003. Available from: <http://www.scielo.br/scielo. php?pid $=$ S0006-87052003000100006\&script $=$ sci arttext $>$. Accessed: Jul. 14, 2011. doi: 10.1590/S0006-87052003000100006.

DALIL, B. et al. Effects of seed viability and water supply on leaf chlorophyll content and grain yield of maize (Zea mays L.). Journal of Food Agriculture Environment, v.8, n.3-4, p.399 402, 2010. Available from: <http://world-food.net/download/ journals/2010-issue 3 4/19(2).pdf>. Accessed: Jun. 14, 2011.

DIAS, D.C.F.S. et al. Teste de condutividade elétrica para a avaliação do vigor de sementes de cebola. Revista Brasileira de Sementes, v.28, n.1, p.154-162, 2006. Available from: <http:// www.scielo.br/pdf/rbs/v28n1/a22v28n1.pdf>. Accessed: Jul. 20, 2011. doi.org/10.1590/S0101-31222006000100022.

FILGUEIRA, F.A.R. Novo manual de olericultura agrotecnologia moderna na produção e comercialização de hortaliças. 3.ed. Viçosa: UFV, 2008. 421p.

NAKAGAWA, J. Testes de vigor baseados na avaliação de plântulas. In: KRZYZANOWSKI, F.C. et al. Vigor de sementes: conceitos e testes. Londrina: ABRATES, 1999. p.2.1-2.21.

GOULART, L.S.; TILLMANN, M.A.A. Seed vigor of rocket seeds (Eruca sativa L.) by controlled deterioration test. Revista Brasileira de Sementes, v.29, n.2, p.179-186, 2007. Available from: $\quad<$ http://www.scielo.br/scielo.php?script=sci_arttext\&pid
$=$ S0101-31222007000200024 $>$. Accessed: Apr. 10, 2011. doi: 10.1590/S0101-31222007000200024.

KOLCHINSKI, E.M. et al. Early growth of soybean plants in relation to seeds vigor. Revista Brasileira de Agrociência, v.12, n.2, p.163-166, 2006. Available from: <http://www.scielo.br/ scielo.php? script $=$ sci_ref $=000078 \&$ pid $=$ S0 101312220090001000 1600009\&lng=en>. Accessed: May 15, 2011. doi: http://dx.doi. org/10.1590/S0101-31222009000100016.

LUCCA-FILHO, O.A. Curso de tecnologia de sementes. Brasília: ABEAS, 1995. 53p.

MACHADO, J.C. Tratamento de sementes no controle de doenças. Lavras: LAPS/UFLA/FAEPE, 2000. 138p.

MAGUIRE,J.D. Speed of germination aid in selection and evaluation for seedling emergence and vigor. Crop Science, v.2, n.2, p.176177, 1962. doi:10,2135qcropsci1962.0011183x000200020033x.

MARCOS FILHO, J. Testes de vigor: importância e utilização. In: KRZYZANOWSKI, F.C. et al. (Ed.). Vigor de sementes: conceitos e testes. Londrina: ABRATES, 1999. Cap.1, p.1-21.

MARCOS FILHO, J. Vigor tests: importance and use. In: KRZYZANOWSKI, F.C.; MARCOS FILHO, J. Fisiologia de sementes de plantas cultivadas. Piracicaba: FEALQ, 2005. 495p.

MARCOS FILHO, J.; NOVEMBRE, A.D.L.C. Avaliação do potencial fisiológico de sementes de hortaliças. In: NASCIMENTO, W.M. (Ed.). Tecnologia de sementes de hortaliças. Brasília, DF. EMBRAPA HORTALIÇAS, 2009. p.185-246.

JIANHUA, Z.; McDONALD, M.B. The saturated salt accelerated aging test for small-seeded crops. Seed Science and Technology, v. $25, \mathrm{n} .1, \mathrm{p} .123-131,1997$. Available from: <http://agris.fao.org/ agris-search/search.do?recordID $=\mathrm{CH} 9700211>$.

LUZ, W.C. Combinação dos tratamentos biológico e químico de sementes de milho. Fitopatologia Brasileira, v.28, n.1, p.37-40, 2003. Avaliable from: doi.org/10.1590/S010041582003000100005. Accessed: Feb. 13, 2011.

RAMOS, N.P. et al. Envelhecimento acelerado em sementes de rúcula (Eruca sativa L.). Revista Brasileira de Sementes, v.26, n.1, p.98-103, 2004. Available from: <http://www.scielo. br/pdf/rbs/v26n1/a15v26n1.pdf>. Accessed: May 25, 2011. doi. org/10.1590/S0101-31222004000100015.

STEINER, F. et al. Seeds germination of salad rocket under different temperatures. Scientia Agraria, v.11, n.2, p.119-124, 2010. Available from: <ojs.c3sl.ufpr.br/ojs2/index.php/agraria/ article/download/16456/11450>. Accessed: Feb. 12, 2011.

VILLELA, F.A et al. Tabela de potencial osmótico em função da concentração de polietileno glicol 6000 e da temperatura. Pesquisa Agropecuária Brasileira, v.26, n.11-12, p.1957-1968, 1991. Available from: <http://webnotes.sct.embrapa.br/pdf/ pab1991/novdez/pab18_novdez_91.pdf $>$. Accessed: Jul. 14, 2011.

ZORATO, M.F.; HENNING, A.A. Influência de tratamentos com fungicidas antecipados, aplicados em diferentes épocas de armazenamento, sobre a qualidade de sementes de soja. Revista Brasileira de Sementes, v.23, n.2, p.236-244, 2001. Available from: <http://www.abrates.org.br/revista/artigos/2001/v23n2/ artigo33.pdf $>$. Accessed: Jul. 14, 2011. 